\title{
Usage of Lysosomal Nanoparticles in Delivering Antibody Cocktail to Developing Fetuses in HIV Mothers
}

Tejas Dhami, BSc Student [1], Muhammad Jan*, BHSc Student [2], Ahmed Mohamed, BSc Student [3]

[1] Department of Human Biology, Stanford University, Stanford, California, United States of America 94305

[2] Department of Health Sciences, McMaster University, Hamilton, Ontario, Canada L8S 4L8

[3] Department of Biology, McMaster University, Hamilton, Ontario, Canada L8S 4L8

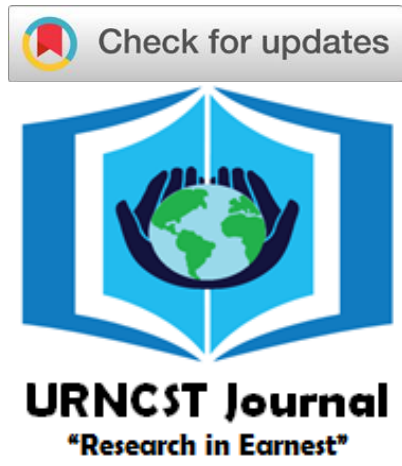

*Corresponding Author: janm1@ mcmaster.ca

\begin{abstract}
Introduction: The placenta is a crucial organ which allows for transfer of nutrients between the mother and fetus. Importantly, the placenta allows for transport of antibodies to the fetal bloodstream through the FcRn receptors inducing passive immunity. However, in HIV-positive mothers who cannot produce antibodies, passive immunity against toxoplasmosis, other, rubella, cytomegalovirus, and herpes (T.O.R.C.H) infections in utero is not plausible. A potential solution utilizing new nanoparticle technology was researched in hopes of delivering $\operatorname{IgG}$ antibodies to the developing fetus.

Methods: We propose using a liposomal nanoparticle filled with the $\operatorname{IgG}$ antibody cocktail to deliver the antibodies necessary for the fetal development. We will use pl-chondroitin sulfate A binding protein (plCSA-BP) to guide our nanoparticle towards the FcRn receptors on the trophoblast membranes of the placenta. Once attached the nanoparticle will degrade after its half-life and release antibodies. We will measure the transfer of antibodies through the ex vivo placental lobule system in combination with western blot. Please note that one side of the placental lobule system would represent the fetal side and one would represent the maternal side.

Results: It's expected that the nanoparticles will attach to trophoblastic layers through the plCSA-BP. The natural FcRn receptors will transfer the antibodies across the placenta to the fetal bloodstream inducing passive immunity in an ex-vivo model.

Discussion: These results may have a noticeable impact on pregnant human immunodeficiency virus (HIV) positive mothers due their ability to enter the fetal system, which will offer passive immunity against T.O.R.C.H viral infections and prevent developmental issues. The absence of antibodies for the fetus can, in some cases, lead to fatality.

Conclusion: We expect the study to show the utility of our nanoparticle design in combating fetal infections, especially in HIV women. This research should be furthered via research into the impacts of medication administration at different trimesters as this has immense potential in advancing a field often on the outskirts of medicine.
\end{abstract}

Keywords: nanoparticle; liposome; FcRn receptor; plCSA binding protein; placenta; fetus; antibody cocktail; HIV (human immunodeficiency viruses)

\section{Introduction}

The placenta is a temporary endocrine organ that acts as a barrier to moderate the flow of nutrients between mother and fetus. Composed of three trophoblastic cell layers (syncytiotrophoblast, cytotrophoblast and the extraembryonic mesoderm), it is peppered with active diffusion and transport proteins which transfer nutrients for the fetus's survival [1]. Chief among these proteins are antibodies, which allow for the development of passive immunity in the fetus. The fetus cannot produce any antibodies independently, and thus must rely on the mother's antibodies to fight off viral infections such as toxoplasmosis, other (i.e. congenital syphilis and viruses), rubella, cytomegalovirus, and herpes (T.O.R.C.H), which can be fatal [2].

T.O.R.C.H viral infections can cross the placental barrier therefore causing fetal defects or miscarriage [3]. The optimal treatment for T.O.R.C.H infections is prevention and thus mothers are conventionally vaccinated to stimulate the production of antibodies that cross the placental barrier into the fetal bloodstream [3]. This transfer of antibodies into the fetal blood acts as passive immunity for the fetus. HIV-positive mothers, however, do not have the ability to produce these antibodies [4]. As such, the 
UNDERGRADUATE RESEARCH IN NATURAL AND CLINICAL SCIENCE AND TECHNOLOGY (URNCST) JOURNAL Read more URNCST Journal articles and submit your own today at: https://www.urncst.com

fetus will not have a passive immune system while maturing in the placenta and will be susceptible to dangerous and potentially life-threatening situations caused by T.O.R.C.H viral infections.

For this study, a nanoencapsulated package containing a cocktail of antibodies targeted to the syncytiotrophoblast could release the cargo near the natural FcRN receptors in the placenta, which induces phagocytosis of $\mathrm{IgG}$ antibodies into the fetal fluid [5]. To target the placenta, plCSA-BP (binding peptide) is used to reach trophoblastic receptors [6]. Once attached, the nanoparticle breaks down and releases the cocktail of antibodies which travels through the trophoblastic barrier into the fetal fluid. Lysosomes are ideal for such a task due to their ability to be conjugated with homing peptides, to their easy manufacturing through polycarbonate membrane extrusion method and to their ability to resist phagocytosis through polyethylene glycol (PEG) layer application.

The aim of this study is to measure the efficacy of liposomal nanoparticles delivering antibody cocktails targeted to the trophoblastic cells for the prevention of T.O.R.C.H viral infections in HIV-positive mothers. This research will also help in the breakthrough of the usage of nanoparticles to treat diseases. Lastly, this research may call for future studies in treating fetal bacterial infections through antibody-loaded nanoparticles.

\section{Methods}

Materials

DSPE-PEG-COOH will be purchased from Avanti Polar Lipids. 1-ethyl-3-(3-dimethylaminopropyl) carbodiimide hydrochloride (EDC), N-hydroxysuccinimide (NHS) will be obtained from Sigma-Aldrich (Missouri, USA). Placental CSA-binding peptides (plCSA-BP, will be purchased from ChinaPeptides Co.,Ltd. (Shanghai, China). Unless stated otherwise, all other materials used will be purchased from Sigma-Aldrich (Missouri, USA).

\section{Synthesis of Liposomes}

To produce the liposomal nanoparticles, we will use the polycarbonate membrane extrusion method [8]. In this procedure, phospholipids dissolved in chloroform are dried into a thin film in a round-bottom flask on a rotary evaporator. The film is further dried under a vacuum for 2 hours. Then, the dry lipid film is put into a $2 \mathrm{~mL}$ buffer solution containing the $50 \mathrm{mM}$ T.O.R.C.H IgG antibody cocktail. This new solution will then be subjected to 6 cycles of freezing and thawing, and then put through extrusion 10 times through $100 \mathrm{~nm}$ pore size polycarbonate membrane to form liposomes.

\section{Conjugation of Liposome Nanoparticles with}

plCSA-BP

Malaria infected erythrocytes have been found to accumulate in the placenta due to their ability to bind to chondroitin sulfate A (CSA) [4]. That said, we will be using the same premise to develop our binding protein. Derived from VAR2CSA, a CSA binding protein expressed in infected erythrocytes, our placental specific binding protein (plCSA) will be able to detect CSA sites on the trophoblast and attach to them.

To attach plCSA-BP to the liposome, we would use a similar protocol established by Zhang et al. in this study [5]. $15 \mathrm{mg}$ of EDC and $5 \mathrm{mg}$ of NHS will be added to pre activate the carboxylic group, and the mixture is mixed for $15 \mathrm{~min}$ at room temperature. Then, $3 \mathrm{mg}$ of plCSA-BP will be dissolved in $500 \mu \mathrm{L}$ of deionized water and then added to the reaction mixture. Then, $350 \mu \mathrm{L} 20 \mathrm{x}$ phosphatebuffered saline is added to the reaction mixture and maintained at $\mathrm{pH}$ 7.0-8.0. After mixing the reaction overnight at room temperature, the excess peptides and other impurities will be removed by triple filtration (AmiconUltra-4 centrifugal filters).

\section{Transfer of plCSA-BP PEG-DSPE to liposomes}

Transfer of plCSA-BP-DSPE-PEG-COOH (plCSA-BP attached to DSPE-PEG-COOH) to preformed liposomes will be induced in a similar method to this study [6]. Aliquots of plCSA micelles will be mixed with preformed liposomes at varying temperature and times at various ratios of the two substrates followed by chromatography on a Sepharose CL-4B column eluted with HEPES buffer ( $\mathrm{pH}$ 7.4).

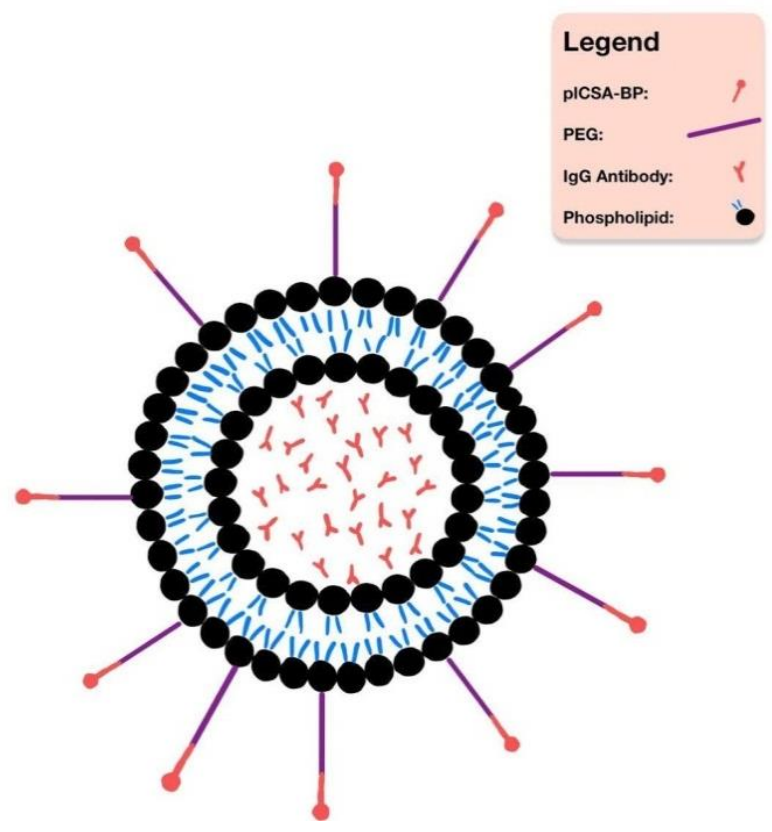

Figure 1. This figure shows the structure of the liposomal nanoparticles. In the center the liposome holds IgG antibodies which are surrounded by phospholipids. Along with the phospholipids PEG molecules coat the surface membrane of the structure, to which the plCSA-BP is attached to. These extrusions of PEG and plCSA-BP are what attach to the trophoblast layers. 
UNDERGRADUATE RESEARCH IN NATURAL AND CLINICAL SCIENCE AND TECHNOLOGY (URNCST) JOURNAL Read more URNCST Journal articles and submit your own today at: https://www.urncst.com

Perfusion of nanoparticles through lobule placental system

The ex-vivo dually perfused human placental lobule system, based on prior research done with human placenta, will be used to measure drug transfer through the placenta due to its ability to preserve its integrity [7]. This ex-vivo system will be maintained at $37^{\circ} \mathrm{C}$ and glucose consumption, $\mathrm{pH}$, and oxygen transfer will be monitored to confirm placental function. The maternal side and fetal side concentrations will be studied to see the transfer of nanoparticles between the placental tissue and fetal blood. IgG antibody concentrations can be detected on the fetal side using western blotting. First, a sample of the blood from the fetal side is collected from the lobule placental system. Then, gel electrophoresis is performed to separate the protein and antibody fragments in that mixture. In this step, antibodies will be separated based on their charge and on their size. The smaller and more charged the polypeptide is, the further it will elute. After transferring the gel electrophoresis bands onto a solid background, we will prepare a fluorescently labelled mixture of antigens. Once the antigen mixture is ready, we will run it through the bands of antibodies and proteins in a similar manner to column chromatography. After this is done, the bands will be analyzed to detect for fluorescence. If fluorescence is present, then we can conclude that the antigens have successfully bound and the presence of antibodies can be confirmed. This would indicate transfer of antibodies from the maternal channel to the fetal channels of the placenta.

\section{Western Blotting}

Western blotting is a technique used to detect our protein of interest from a mixture of proteins [8]. It will be used to identify IgG antibodies concentration on the fetal side. This will be done to determine if successful transmission of our cocktail of antibodies occurred through the trophoblast layers. A sample of $1 \mathrm{ml}$ will be recovered from the fetal side and will be run through SDS-PAGE gel electrophoresis. The results will then be analyzed and fluorescently labeled FcRN receptors will be used to detect the presence of $\mathrm{IgG}$ antibodies.

\section{Results}

Due to the attachment of the plCSA-BP to the PEG molecules which are located on the liposome, we predict that successful binding between the nanoparticle and the trophoblast layers will be observed. After this linkage, we expect the nanoparticle to release its cargo by the trophoblast layers on the maternal side due to the nanoparticle degrading. We predict that around $40 \%$ of our antibody cocktail will be transferred to the fetal side. Thus, the cocktail antibody packed into the nanoparticle will be released and we expect it to be absorbed into the fetal side of the placenta through the FcRN receptors due to these reasons [5]. The PEGylation will aid in getting the nanoparticle to the trophoblast layers without reacting anywhere else. Once the antibodies cross, the cocktail can then be provided to the fetus, allowing for the development of the passive immune system it requires. We also predict a very high encapsulation efficiency of $>80 \%$ because our nanoparticles will be coated with PEG layers. These layers will offer a longer half-life for our nanoparticles to reach the placenta. Furthermore, we anticipate a high binding efficiency of $>\simeq 85 \%$ due to the specificity of our ligand protein, which solely binds to the FcRn receptors of the placenta [3]. Thus, we're expecting to find a very high percentage of successful binding between this receptor and its ligand.

However, since this technique is extremely novel, we expect to encounter certain challenges. The first anticipated challenge will be the possibility of the plCSA binding protein not attaching the trophoblast layers. This will mean that the cargo will not release near the placenta and thus not allow for a higher transfer of antibodies between the mother and child. To overcome this, is by measuring the $\operatorname{IgG}$ antibodies on both sides of the placenta. Western blotting can help us identify the concentrations of the antibodies on both sides of the placenta. Secondly, the liposomal nanoparticle's half-life is very short however with the addition of the PEG layer, its half-life is increased. Our goal is to keep the nanoparticle attached to the FcRN receptors on the trophoblastic walls until it is degraded after around 5 hours [11]. After its degradation, the lipid membrane will disintegrate and the IgG antibody cocktail will be released near the trophoblastic wall. The antibodies will then be uptaken naturally through the trophoblast and will enter the fetal bloodstream through the umbilical cord.

\section{Discussion}

Though we do not entirely understand the potential impacts of antibodies on fetal development, there are a few inferences we can make. Particularly, according to research conducted by Dr. Willis and her colleagues, higher concentrations of antibodies circulating in the nervous system are evident in a variety of neurological disorders [11]. In adults, antibodies are unable to damage the brain due to the Blood Brain Barrier (BBB), which does not completely develop until just prior to birth. As such, in utero, the brain is more exposed to antibodies, which, if highly concentrated, have the potential to drastically damage its function $[12,13]$. This is especially clear in the transference of antibodies from mother to fetus often used in combating Myasthenia Gravis which, in some cases, results in the development of abnormalities in the central nervous system [14-16]. Outside of the nervous system, exposure of the fetus to the maternal rituximab antibody has shown to lower the B lymphocytes count in the fetus, increasing the fetus's vulnerability to infection $[11,12]$. This increases the fetus's vulnerability to infection. Although high antibody concentrations pose a threat to the fetus, in lower concentrations the possibility of damage can be controlled. As long as the nanoparticles carrying these antibodies are delivered in manageable concentrations, 
UNDERGRADUATE RESEARCH IN NATURAL AND CLINICAL SCIENCE AND TECHNOLOGY (URNCST) JOURNAL Read more URNCST Journal articles and submit your own today at: https://www.urncst.com

nanoparticle treatment can prove effective, especially with diseases resulting in high mortality rates. Moreover, in comparison to other methods of fetal drug delivery, which can be extremely dangerous, nanoparticles have the potential to revolutionize the field. The field of obstetrics has a limited number of medications that can be utilized in fetal drug delivery. Between 1990 and 2008, only three new fetal medications had been licensed [15]. Additionally, a great portion of fetal medications have concerning sideeffects. A majority of fetal medication consists of small particles that cross the placenta via diffusion [13]. This in turn is extremely damaging to the placenta as it leads to serious fetotoxicity [13]. In summary, nanoparticles do not solely rely on passive diffusion but accurate binding to transfer across the placenta, limiting damage to the organ [13].

Though our current nanoparticle design has many extremely useful attributes, it also possesses one major weakness: susceptibility to degradation. Due to the inherent weakness of the nanoparticle membrane, it is easily degraded by other biological molecules in the bloodstream. This can be problematic since a majority of these nanoparticles tend to degrade prior to ever reaching the trophoblastic membrane, which drastically reduces the quantity of medication delivered to the fetus. To counter this issue, PEGylation, the process by which polyethylene glycol polymer chains are amalgamated to a specific molecule, can be utilized. PEGylation aids in combating degradation as the hydrophilic tails of the polyethylene glycol encapsulate the nanoparticle, protecting it from aggregation, opsonization, and phagocytosis. This ability of PEGylation was made especially clear by Dr. Klibanov, a professor of chemistry and bioengineering at the Massachusetts Institute of Technology, who displayed how PEGylation increases the half-life of liposomes circulating in our blood system [11]. As such, by reducing interaction between the nanoparticle and other biological molecules, PEGylation drastically reduces degradation and ensures more efficient medication delivery.

HIV-positive mothers, due to their lack of an immune system, have long been unable to protect their developing fetuses. This research paper offers methods to develop an efficient nanoparticle to target the placenta and supply the fetus with a cocktail of antibodies, against T.O.R.C.H viral infections, to ensure its survival. As such, the cocktail will be able to supplement the mother's lack of an immune system and prevent the onset of developmental issues in the fetus. Moreover, though our method has focused primarily on utilizing nanoparticles to deliver medication in utero, it is equally possible for scientists to employ our procedure in targeted delivery of medication to other organs by changing the specific binding proteins conjugate onto the surface of our nanoparticles to correlate with binding receptors on the tissue of the target organ.

Lastly, though modern medicine has made huge strides in combating diseases prevalent in the west, HIV and other diseases, which disproportionately affect developing countries, are often pushed to the outskirts of treatment. As such, it is necessary to pursue nanoparticle research further, so as to ensure HIV-positive mothers around the world, but especially in Sub-Saharan Africa and Southeastern Asia, are able to combat this disease effectively.

\section{Conclusions}

We have outlined a method to create a PEGylated nanoparticle, with the plCSA binding protein, which could be effective for delivering medication in utero. Our research is especially useful to HIV-positive mothers, who are immunocompromised and to the general field of embryology. Furthering of this research would allow physicians to be better prepared in countering otherwise fatal fetal diseases Additionally, in sub-Saharan communities, HIV-positive women have to endure incredible discrimination and societal seclusion due to HIVs inhibition of traditional gender associations (childbearing). Though modernization, and increased education, is aiding in combating these cultural norms, progress has been slow. As such, though our research is not a long-term solution, it offers a solution for HIV positive mothers to plan a safe pregnancy in which there is reduced danger to their child. Building on our research, we believe that nanoparticle treatment regimens and administration concentrations need to be optimized for each stage of pregnancy. As briefly explored in our discussion, the bloodbrain barriers development influences the specific amount of nanoparticles that could be delivered to the fetus. As a result, further research would clarify how much and/or how little medication can be safe during each trimester.

\section{List of Abbreviations Used}

URNCST: Undergraduate Research in Natural and Clinical Science and Technology

T.O.R.C.H: toxoplasmosis, other, rubella, cytomegalovirus, and herpes

plCSA-BP: plCSA binding protein

PEG: polyethylene glycol

CSA: chondroitin sulfate A

BBB: Blood Brain Barrier

\section{Conflicts of Interest}

The authors declare that they have no conflict of interests.

\section{Ethics Approval and/or Participant Consent}

Our study did not require any ethics approval or participants consent. Our study is a research protocol with novel methods based on past research.

\section{Authors' Contributions}

AM: Contributed to the writing of the introduction, methods sections 2.3 and 2.6, results and gave final approval of this version to be published. 
MJ: Contributed in creating the introduction. Made the methods $(1,2,4,5)$ and gave final approval of this version to be published.

TD: Contributed in creating the discussion, introduction and conclusion and gave final approval of this version to be published.

\section{Acknowledgements}

We would like to acknowledge our mentor, Sonya Kouthouridis for her guidance. We are thankful for all the comments and contributions she has offered us to ameliorate this research paper. Furthermore, we want to acknowledge URNCST in preparing a mentorship program for undergraduates to learn from.

\section{Funding}

This study was not funded.

\section{References}

[1] Bauer MK, Harding JE, Bassett NS, Breier BH, Oliver $\mathrm{MH}$, Gallaher $\mathrm{BH}$, et al. Fetal growth and placental function. Molecular and Cellular Endocrinology. 1998 May 25;140(1):115-20. https://doi.org/10.1016/S03037207(98)00039-2

[2] Silasi M, Cardenas I, Racicot K, Kwon J-Y, Aldo P, Mor G. VIRAL INFECTIONS DURING PREGNANCY. Am J Reprod Immunol. 2015 Mar;73(3):199-213. https://doi.org/10.1111/aji.12355

[3] Faucette AN, Pawlitz MD, Pei B, Yao F, Chen K. Immunization of pregnant women: Future of early infant protection. Hum Vaccines Immunother. 2015 Sep 14;11(11):2549-55z. https://doi.org/10.1080/21645515 .2015 .1070984

[4] Singh L, Mishra S, Prasanna S, Cariappa MP. Seroprevalence of TORCH infections in antenatal and HIV positive patient populations. Medical Journal, Armed Forces India. 2015 Apr;71(2):135. https://doi.org/10.1016/j.mjafi.2014.12.009

[5] Lozano NA, Lozano A, Marini V, Saranz RJ, Blumberg RS, Baker $\mathrm{K}$, et al. Expression of FcRn receptor in placental tissue and its relationship with IgG levels in term and preterm newborns. Am J Reprod Immunol N Y N 1989. 2018 Sep;80(3):e12972. https://doi.org/10.1111/aji.12972

[6] Zhang B, Tan L, Yu Y, Wang B, Chen Z, Han J, et al. Placenta-specific drug delivery by trophoblast-targeted nanoparticles in mice. Theranostics. $2018 \mathrm{Apr}$ 9;8(10):2765-81. https://doi.org/10.7150/thno.22904

[7] Forestier F, de Renty P, Peytavin G, Dohin E, Farinotti R, Mandelbrot L. Maternal-fetal transfer of saquinavir studied in the ex vivo placental perfusion model. American Journal of Obstetrics and Gynecology. 2001 Jul 1;185(1):178-81. https://doi.org/10.1067/mob.2001 .113319

[8] Mahmood T, Yang P-C. Western Blot: Technique, Theory, and Trouble Shooting. N Am J Med Sci. 2012 Sep;4(9):429-34. $\quad$ https://doi.org/10.4103/1947-2714 .100998

[9] Shi G, Guo W, Stephenson SM, Lee RJ. Efficient intracellular drug and gene delivery using folate receptor-targeted $\mathrm{pH}$-sensitive liposomes composed of cationic/anionic lipid combinations. J Control Release Off J Control Release Soc. 2002 Apr 23;80(1-3):30919. https://doi.org/10.1016/s0168-3659(02)00017-2

[10] Ishida T, Iden DL, Allen TM. A combinatorial approach to producing sterically stabilized (Stealth) immunoliposomal drugs. FEBS Lett. 1999 Oct 22;460(1):129-33. https://doi.org/10.1016/s0014-5793 (99)01320-4

[11] Wills S, Cabanlit M, Bennett J, Ashwood P, Amaral DG, Van de Water J. Detection of autoantibodies to neural cells of the cerebellum in the plasma of subjects with autism spectrum disorders. Brain Behav Immun. 2009 Jan;23(1):64-74. https://doi.org/10.1016/j.bbi.2008 .07 .007

[12] Diamond B, Huerta PT, Mina-Osorio P, Kowal C, Volpe BT. Losing your nerves? Maybe it's the antibodies. Nat Rev Immunol. 2009;9(6):449-56. https://doi.org/10.1038/nri2529

[13] Kowal C, DeGiorgio LA, Nakaoka T, Hetherington H, Huerta PT, Diamond B, et al. Cognition and immunity; antibody impairs memory. Immunity. 2004 Aug;21(2):179-88. https://doi.org/10.1016/j.immuni.2004.07.011

[14] Vincent A, Roberts M, Willison H, Lang B, NewsomDavis J. Autoantibodies, neurotoxins and the nervous system. J Physiol Paris. 1995;89(3):129-36. https://doi.org/10.1016/0928-4257(96)80110-0

[15] Dalton P, Deacon R, Blamire A, Pike M, McKinlay I, Stein $\mathrm{J}$, et al. Maternal neuronal antibodies associated with autism and a language disorder. Ann Neurol. 2003 Apr;53(4):533-7. https://doi.org/10.1002/ana.10557

[16] Murphy K, Weaver C. Janeway's Immunobiology. Garland Science; 2016. 925 p.

[17] Fisk NM, Atun R. Market Failure and the Poverty of New Drugs in Maternal Health. PLoS Med [Internet]. 2008 Jan [cited 2020 Nov 2];5(1). https://doi.org/ $\underline{10.1371 / \text { journal.pmed.0050022 }}$ 
UNDERGRADUATE RESEARCH IN NATURAL AND CLINICAL SCIENCE AND TECHNOLOGY (URNCST) JOURNAL

Read more URNCST Journal articles and submit your own today at: https://www.urncst.com

\section{Article Information}

Managing Editor: Jeremy Y. Ng

Peer Reviewers: Sonya Kouthouridis, O'Llenecia Walker

Article Dates: Received Nov 03 20; Accepted Jan 16 21; Published Feb 0121

\section{Citation}

Please cite this article as follows:

Dhami T, Jan M, Mohamed A. Usage of lysosomal nanoparticles in delivering antibody cocktail to developing fetuses in HIV mothers. URNCST Journal. 2021 Feb 01: 5(2). https://urncst.com/index.php/urncst/article/view/214

DOI Link: https://doi.org/10.26685/urncst.214

\section{Copyright}

(C) Tejas Dhami, Muhammad Jan, Ahmed Mohamed. (2021). Published first in the Undergraduate Research in Natural and Clinical Science and Technology (URNCST) Journal. This is an open access article distributed under the terms of the Creative Commons Attribution License (https://creativecommons.org/licenses/by/4.0/), which permits unrestricted use, distribution, and reproduction in any medium, provided the original work, first published in the Undergraduate Research in Natural and Clinical Science and Technology (URNCST) Journal, is properly cited. The complete bibliographic information, a link to the original publication on http://www.urncst.com, as well as this copyright and license information must be included.

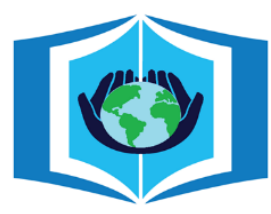

\section{URNCST Journal \\ "Research in Earnest"}

\section{Funded by the Government of Canada}

\section{Canadằ}

Do you research in earnest? Submit your next undergraduate research article to the URNCST Journal!

| Open Access | Peer-Reviewed | Rapid Turnaround Time | International |

| Broad and Multidisciplinary | Indexed | Innovative | Social Media Promoted |

Pre-submission inquiries? Send us an email at info@urncst.com | Facebook, Twitter and LinkedIn: @ URNCST

Submit YOUR manuscript today at https://www.urncst.com! 